\title{
Dangling between death and hope: An HIV and AIDS gender-sensitive re-reading of Psalm 6
}

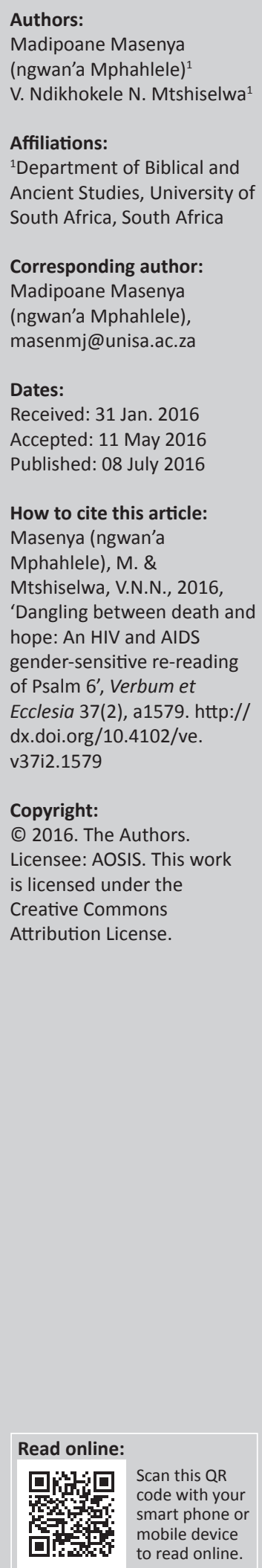

The genre of laments (both individual and communal) can be traced historically, even up to today, to periods of crisis. The psalms of lament in the Hebrew Bible point to periods both of national crisis such as wars, exile, and individual crisis, namely attacks from enemies and illness among others. The crisis of the exile was typified by death (in the literal and metaphorical sense), pestilence, disease and war. It was also typified by hope as some of the prophets such as Jeremiah could prophesy both doom (read: death) and salvation (read: hope). If there is any crisis that people of African descent, particularly those located within the sub-Saharan continent, have ever come to experience it is the crisis brought by the pandemic of HIV and AIDS. The pandemic is better approached by scholars who hold the view that it is multisectoral. According to the latter view, the pandemic impacts the social, the economic, the religious or spiritual, and the psychological lives of both the affected and the infected. It is a justice issue. It can thus not be relegated to the individual because it is communal. Is it any wonder that in 2002 the members of the Circle of Concerned African Women Theologians set out to theologise and conduct God-talk that would be both gender- and HIV and AIDSconscious? In this article, we engage the works of Circle theologians and biblical scholars to see what kind of reading could emerge if we re-read the lament psalm, such as Psalm 6, gender and HIV and AIDS consciously.

Intradisciplinary and/or interdisciplinary implications: In this article, the disciplines of biblical studies, gender studies, and HIV and AIDS studies, among others, converge as the authors draw from Circle theologies and biblical hermeneutics to re-read Psalm 6 through an HIV and AIDS lens. In the process, issues such as patriarchy, poverty and social justice are also dealt with.

The search for a readily identifiable situation as the context for understanding the laments may, however, be illusory or unnecessary. The language of these psalms with its stereotypical, generalizing, and figurative style is so open-ended that later readers, on the one hand, are stopped from peering behind them to one or more clearly definable sets of circumstances or settings in life, and on the other hand, are intentionally set free to adapt them to varying circumstances and settings. (Miller 1986:8, [authors' own italics])

\section{The context of our reading: South Africa within the sub-Saharan African continent}

An HIV and AIDS gender-sensitive biblical hermeneutic is first and foremost contextual. It seriously takes into account the experiences of HIV and AIDS women sufferers. As African women are the hardest hit by the pandemic of HIV and AIDS in South Africa, our HIV and AIDS genderconscious re-reading of Psalm 6 will be informed first and foremost by the experiences of these women. Before we give a brief overview of African women's experiences, the following narrative is in order.

In December 2014, Madipoane Masenya (ngwan'a Mphahlele) participated in an HIV and AIDS workshop which occurred at McCormick Theological Seminary in Chicago, IL, USA. One of the keynote speakers was the Rev. Dr Jeremiah Wright, Bishop Emeritus at the Trinity Church in Chicago. While Dr Wright commended South Africa (cf. at least compared to the USA) for the strides the country has made regarding the fight against HIV and AIDS, he also added a critique. Dr Wright noted that it was in South Africa that the President is reported to have cleansed himself from the HIV in a shower! Although the preceding critique could be viewed as based on an issue that may be deemed to belong to the dustbin of history, an important question we ask is: what may the institution of polygyny contribute to our communal struggle in the fight against the pandemic of HIV and AIDS? Although it might be argued that the (mostly younger) women who are now South Africa's many first ladies were not coerced into such a risky form of marriage in 
the HIV and AIDS context, the initiators of marriage in our patriarchal African contexts are usually men. The critique by Dr Wright above serves as a fitting introduction to the topic of the present article, that is, the act of dangling between death and hope as a people both infected and affected by HIV and AIDS: Death in the sense that factors such as dangerous masculinities (cf. polygyny and engaging in unprotected sex among others), but also hope in the sense that the country has, since the so-called Thabo Mbeki's denialism dispensation, made strides of success in her fight against HIV and AIDS.

As scholars within the South African Biblical sciences though, we need to hasten to argue that we cannot own the success that has been made so far. Why? Very little, if any, biblical scholarship in South Africa integrates HIV and AIDS studies in their disciplines, yet, as Dube (2012) has cautioned:

In the HIV and AIDS context, where about sixty million members of the world have been infected, with a third of these dead and 15 million children orphaned, where the social justice and human rights link are so central, the classy, text-centred academic biblical approach is challenged to expand its boundaries. It becomes evident that it is an approach that is vulnerable to silence and indifference to the social concerns of its world and communities. It becomes evident that, many times, academic biblical studies largely becomes research for the sake of research, whose findings hardly ever seek to inform social practice and social transformation. (p. 506)

Like many Circle of Concerned African Women Theologians (hereinafter referred to as Circle), we argue in this article that there is a link between the pandemic of HIV and AIDS and patriarchy, poverty and non-literacy among others. HIV and AIDS is thus a justice issue. We also acknowledge that on the African continent and its diaspora, HIV and AIDS carries a feminine face. As such, and as already noted, we will deliberately approach the topic of this article, as far as it is possible, informed by the experiences of African-South African women - who are the hardest hit by the pandemic of HIV and AIDS. In our view, the pandemic, like the event of exile in biblical Israel, has thrown African people into a moment of crisis. The moment of crisis calls for a lament not only of affected individuals but a communal lament. Commenting on the works (read: lament) of Circle African women theologians, Dube (2009) reasons:

These expressions are a scream, a clarion call, a lament for transforming the world towards justice for, to and with all members of the earth's community. These expositions underlie that injustice in any form, to any member of the earth's community, is at the end of the day, the root cause of ill-health. They expose that gender oppression is incontrovertibly violent to both sexes. They underline the fact that poverty might be perpetuated by a few world powers and national leaders, but it is, irreducibly, violence to those who are dehumanized through poverty, violence that cannot be restricted to certain spaces and people, but one that always finds a way of spilling over into the safe havens of the rich and the powerful. (p. 175)

We will thus engage the lament of Psalm 6, from an HIV and AIDS gender perspective. Within the South African context, it should be noted with Masenya (ngwan'a Mphahlele) (2010) that due to a variety of factors which have contributed to the marginalisation of African women, the HIV and AIDS pandemic has only come to exacerbate their situation ${ }^{1}$. The factors are, but not limited to: (1) Foreign Patriarchal Systems, (2) The Emasculation of an African Man and (3) The Challenge of HIV and AIDS (and the Bible). A brief overview of the preceding factors will serve as a background to reveal the need for an HIV and AIDS gender-sensitive reading of biblical texts. Biblical scholars who take seriously the plight of the victims of HIV and AIDS in South Africa, need to emulate Circle theologians by deliberately engaging in an HIV and AIDS gender-conscious biblical hermeneutic. As already noted, such a hermeneutic is first and foremost contextual. It is committed to the plight of HIV and AIDS sufferers. As a gender-sensitive hermeneutic, also given the feminine nature of the pandemic in African contexts, an HIV and AIDS gender-sensitive biblical hermeneutic advances the experiences of African women HIV and AIDS sufferers. Before we engage with the lament in Psalm 6, also in our attempt to situate the context of our reading, in the following paragraphs, we briefly discuss the marginalising factors.

\section{Foreign patriarchal systems}

The demonisation of African cultures by colonial masters and many a missionary who colluded with the colonials, apartheid teachers and preachers is well-documented (cf. Dube 2000; Hinga 1992:187; Mashau 2003:123-144; Tefo 2003:165-182). Apart from imperialism and its negative impacts on African women's lives, African patriarchy was already in place in pre-colonial Africa. We would therefore argue, contrary to some black feminist scholars (cf. Rivkin 1994; Steady 1994) who tend to blame African patriarchy solely on European imperialism. We agree with some of the Circle theologians (cf. Amoah \& Oduyoye 1989:35-46) that African women were already limping in pre-colonial Africa on account of patriarchy. ${ }^{2}$ Oduyoye (1994) reasons that:
... it is too easy to lay the blame solely at the feet of westernization. We know that in the African religio-cultural heritage is to be found the seeds of objectification and marginalization of women. Colonial policies simply helped the process along, and it succeeded to the extent that it was advantageous for African men. (p. 173)

One therefore does not need to be born in pre-colonial Africa to agree that even before the white man landed with his European patriarchy on the African shores, he already found one on the African continent. In that sense, while the situation of African women was already limping on account of patriarchy, the new systems, that is, colonialism and apartheid

1.In this sense, while it was limping, HIV and AIDS made African women to climb the mountain! The Northern Sotho proverb, wa re o e bona e hlotša, wa e nametša thaba [while you saw it limping, you still made it to climb a mountain], is fitting here.

2.According to Okure, humanity as a whole, both black and white, men and women, has been limping from time immemorial (2003:71-95). She asserts: 'So it is with patriarchy and humanity. From the time of Genesis 3, humanity has been limping. patriarchy and humanity. From the time of Genesis 3, humanity has been limping. Though divinely inspired, Genesis 3 itself has been written from the perspective of
the limping humanity. The story of the fall grows out of the biblical author's awareness that the situation by which the woman is treated as the man's property awareness that the situation by which the woman is treated as the man's property
and dominated by the man in all walks of life is a result of sin, not the created order willed by God' (Okure 2003:86). 
in the case of South Africa, only made it to climb a mountain. As an African woman's situation was intensified by patriarchy within the broader South African context, an African man became emasculated.

\section{Challenged masculinities?}

It will be an exaggeration to argue that there were no poor people in pre-colonial Africa. Proverbs and wisdom sayings, which refer to orphans and poor people, as well as the care which they were supposed to receive from their communities throw light on the existence of the preceding category of people (cf. also Masenya [ngwan'a Mphahlele] 2005a:26). Amoah (2009:207-217) observes that there is no word for poverty in the Ghanaian indigenous languages. Equally true though, is the point that poverty among Africans was aggravated then and even now by foreign systems (cf. Rodney 1982).

In the process of 'Africa being underdeveloped by Europe' to use part of the title of Rodney's book, (cf. Rodney 2009), African peoples were stripped of their lands even as they were forced into a new system of labour to earn the new form of money (cf. Mofokeng 1986:113-128; Masenya [ngwan'a Mphahlele] 2004:147-148; 2005a:22-24). In Southern Africa, the system of migrant labour resulted not only in the disruption of the African family (cf. Kretzschmar 1992; Masenya [ngwan'a Mphahlele] 2005a:25a-26; Phiri 2003:12-13) but also in further devaluing work done in the private sphere of the home by African women. On account of the Group Areas' Act of 1950 enacted by the apartheid South African government, African women had to remain in the rural areas to take full responsibility of their families. In the process, while African men's egos were inflated by the new 'superior' form of wages earned from their white masters, their egos became challenged not least due to the low-quality jobs which most of them were doing. An African man was thus emasculated by the kind of treatment which he received from many a white man (cf. Biko in Masenya [ngwan'a Mphahlele] 2008:141-155). Back in the private sphere of the home, their wives 'naturally' became the objects of their anger and frustration.

The preceding scenario reminds us of an African-American context. In their book titled Gender Talk: The Struggle for Women's Equality in African-American communities, Cole and Guy-Sheftall (2004) reveal the link between systemic violence such as racism and violence on black women by black men. They argue that '... the persistence of racism must be understood in any analysis of Black definitions of masculinity that certainly impact Black gender politics as well ...' (Cole \& Guy-Sheftall 2004:134). Their quotation of sociologist Robert Staples regarding the difficulty of poor African-American men to achieve appropriate gender roles is revealing: ' ... role failure results in conceptions of manhood that are available to them - impregnating females, fathering many children, especially boys and having many sexual conquests and sexual relationships' (Cole \& Guy-Sheftall 2004:169).
With respect to the South African context, statistics reveal that among cases of sexual violation against women reported to the police, a higher proportion of $55.3 \%$ was said to have been committed by strangers (Hirschowitz, Worku \& Orkin 2000:2). In addition, Hirschowitz et al. (2000) remark:

Among white women interviewed in the survey, $7.3 \%$ reported being raped. This was the largest percentage within each population group, followed by coloureds $(6 \%)$... When calculated as a proportion of the total number of women who had reported being raped $(N=471)$, African women represented the largest proportion $(66.7 \%)$, followed by coloured women $(19.5 \%)$, then white (11.4\%) and Indian women (2.1\%). (p. 17)

Based on the preceding remark, it may be argued that violence against women is a perturbing reality in South Africa. The link between gender-based violence and HIV and AIDS is irrefutable as many a woman contracts the virus in the event of rape. Masenya (ngwan'a Mphahlele) (2012:213-214) alerts us that violence against women is perpetrated not only by strangers but also by family members. The idea of physical abuse at the hands of family members rather than merely strangers brings to mind Olojede's (2015:87-98) contribution entitled Absence of Wife battering in Old Testament Narratives: A literary omission or a cultural aberration? Wife battering is the form of physical abuse against a woman, an abuse which is perpetrated by her husband. The physical abuse of women by their husbands is a disturbing reality which might be pointing to the emasculation of perpetrators. On account of fear of battering, some women would not dare to refuse their unfaithful husbands unprotected sex.

Furthermore, Sociologist Benjamin P. Bowser proposes that men of all social classes who experience frustrated instrumental and social roles put more stress on sexuality (Bowser 1994:123). In his view, this exaggerated sexuality leads to competition with other black men, which often leads to violence.

Chitando and Chirongoma (2008), writing from a Zimbabwean perspective, argue:

The male quest for sexual pleasure has had negative consequences, for women, children and men themselves in the era of HIV. Although there are factors that facilitate the spread of HIV, including poverty, migrant labour, international justice and others, patterns of male sexual behavior require urgent attention...Unfortunately, many men strive to live up to the ideal of competence and conquest in the area of sexuality. Most men do not invest in intimacy. They regard sex as a form of entertainment wherein they must be the ones who derive maximum satisfaction. Men have been pampered to believe that their egos must be massaged, and that they must always have things their own way. (pp. 58-59)

Such problematic definitions of masculinities can easily be made to collude with those of their kind found within biblical texts. If these are not sanctioned by life-affirming biblical hermeneutics and theologies (a rare type even in the postapartheid South African context), particularly in the era of HIV and AIDS, our struggle against the pandemic is far from being won. 


\section{The challenge of HIV and AIDS and the bible}

The lamentable state of affairs about the glaring inequalities between women and men in the South African church, family and society at large has been 'made to climb a mountain' today by the prevalence of the deadly pandemic of HIV and AIDS. African women scholars, particularly members of the Circle, have spilled a lot of ink on the gendered nature of the pandemic (cf. Dube \& Kayoro 2004; Hinga et al. 2008; Mwaura 2008; Phiri 2003; Phiri \& Nadar 2006). As has already been noted, research has revealed that the pandemic thrives more on poverty-stricken parts of the globe. It is no wonder that with an average African woman being at the bottom of the South African socio-economic ladder, coupled with the susceptibility of female biology to the HIV-infection, even in our context, the pandemic has mostly assumed a black feminine face.

Some of the above-mentioned Circle theologians further revealed that harmful cultural and religious practices also contribute to the spread of HIV among African women (cf. Ayanga 2008; Chauke 2003; Masenya [ngwan'a Mphahlele] 2003; Phiri 2003). Some of them have revealed how sacred texts have been used in an unhelpful way towards the struggle for gender justice in the time of HIV and AIDS (Masenya [ngwan'a Mphahlele] 2006; Nadar 2004). Others have shed light on the risk associated with heterosexual marriage in the era of HIV and AIDS (cf. Mbuwayesango 2007; Masenya [ngwan'a Mphahlele] 2007).

With the preceding brief background to some of the challenges facing African-South African women in the era of HIV and AIDS, also having been enabled to situate our gender-sensitive HIV and AIDS hermeneutic in context, we now offer a gender-sensitive HIV and AIDS re-reading of Psalm 6, a lament psalm from a sick person (cf. Habtu 2006:613; McCann 1996:703; Rakes 2002:292). Before we do that though, we would like to argue that the experience of exile and some of the events prior to it revealed that the people of Judah were dangling between death and hope.

\section{Dangling between death and hope: Exile and lament in biblical Israel}

If there is any major crisis that ancient Israel ever came to experience, that was the crisis brought by her experience of the exile. The moment was typified by death (in the literal and metaphorical sense) or war or the sword, pestilence (read: disease) and famine. The moment of exile was at the same time typified by hope as some of the prophets could prophesy both doom (read: death) and salvation (read: hope) (cf. for example Isaiah and Hosea in the preceding category). Even a prophet of doom such as Jeremiah has scattered within his prophetic tradition prophecies of hope and return. ${ }^{3}$ A reading of the text of Jeremiah reveals the following recurring acts of punishment:

3.'Now therefore, thus says the Lord, the God of Israel, concerning this city of which you say "It shall be delivered into the you say, "I shall be delivs the Lord, and by famine, and by pestilence": See, I will gather them out of all countries whereve I have driven them in My anger, and in My fury, and in great wrath; and I will bring them again to this place, and I will cause them to dwell safely. And they shall be My people, and I will be their God. And I will give them one heart and one way, that they may fear Me forever, for their good and for their children after them' (Jeremiah 32:36-39 MEV) sword or war, pestilence and famine. On account of Israel's deviation from her covenant relationship with Yahweh, Jeremiah prophesied an impending exile which would be carried out by the power from the North. Nebuchadnezzar, the king of Babylon, would be used by Yahweh as Yahweh's servant to punish the people of Judah. Amidst the deathdealing prophesies though, Jeremiah also exhorted the nation that there was still room for salvation if they were to repent and forsake their evil ways.

It would not be an exaggeration to argue that during the transition between the period before exile and the Babylonian exile itself, the nation was trapped between death and hope. Theirs was a dispensation that called for lament and in particular a communal lament. Is it any wonder that the Psalter, one of the influential literatures in the Hebrew Bible, is replete with psalms of lament, that is, both the individual and communal laments? Although some of the psalms originated within a pre-exilic setting, in the context of exile and a post-exilic setting, such psalms would have assumed a different meaning. Worthy of note is the observation that also within these psalms of lament, a creative tension between doubt (read: hopelessness or doom) and faith (read: hope) is maintained. Such a tension had to be maintained because as Mandolfo (2014) has rightly argued:

together, these two ideological positions - doubt and faith - offer a profound reflection on human experience. Faith without doubt is myopic; while doubt without faith runs the danger of sliding into existential meaninglessness. (p. 125)

What is heartening though is that for those who have ears to hear and eyes to see, it was clear that even amidst the crisis, there was already light at the end of the tunnel. We now turn to the lament in the book of Psalms.

\section{Lamenting her way through Psalm 6}

In our view, what would draw gender-sensitive scholars to the Psalter as a whole is that, unlike the prophetic corpus that seems to have been the preoccupation of a few people, mostly men, the Psalter is a storehouse of a variety that forms the package we call human experience. The fact that we cannot lay hold on the identity of the original psalmist who uttered the words of the lament of Psalm 6 may not bother an HIV and AIDS gender-identified reader of the psalm. In our view, what matters most, is the apparent resonance of the content of the lament with the present day experiences of HIV and AIDS sufferers ${ }^{4}$. In Miller's view, it does not really matter whether sickness is understood both literally and metaphorically in the Psalter. The bottom line is that however sickness is understood, sickness has the capacity to leave us (i.e. people who read the psalms in the contexts of their production, and we, who are the later readers) not only helpless, and also not being able to take control. Sickness also leaves us without hope. Continues Miller (1986):

4.In a more or less similar vein, Goldingay (2006) argues: 'But even if we do not know precisely what that experience was, our experience resonates with that human experience and enables us to interpret it' (p. 31) 
One feels helpless, oppressed by forces outside oneself - and indeed that is the situation. Moaning, groaning, sighing, tears, the experience, Why is this happening to me? - all are aspects of the distress of sickness. (p. 26)

It is an indisputable fact that feminist scholars use human (read: female) experience as a point of departure in their hermeneutical endeavours (Fontaine 1992:145-152). Is it any wonder that Nancy L. Declaissé-Walford (2012) would argue, 'The words of the psalmists are genderless and timeless, the words of every person in every time and place' (Walford 2012:224). An individual lament like Psalm 6, with its revelation of the individual experience of sickness from the one who laments, may be found attractive particularly to individual HIV and AIDS African women sufferers. Many commentators are agreeable that Psalm 6 (cf. also Psalms 13, $22,28,38$ and 102) is one of the psalms whose content reveals sickness, whether literally or metaphorically. According to McCann (1996:703), for example, the language and imagery used in this psalm suggest that Psalm 6 was originally composed by a sick person as a prayer of healing (McCann (1996:703) (cf. also Habtu 2006:613; Rakes 2002:292). Although we are aware that some of the HIV and AIDS sufferers would not regard themselves as being sick (read: patients), we found Psalm 6 to be a fitting psalm for readers who choose to read from an HIV and AIDS gender-sensitive perspective. On the latter aspect, though we are aware of authors (cf. Goldingay 2006:31-32; Miller 1986:56-57) who see a close link between the psalm and the prayer of Hannah in 1 Samuel 1 , we are not persuaded that the psalm might have been authored by a woman.

On the other hand, Nancy L. Declaissé-Walford (2012) is of the view that the male authorship of some of the psalms might be problematic. The superscriptions to the psalms could thus serve as a hindrance to 'hearing the voice of all humanity' (Declaissé-Walford 2012:224) in the Psalter, because David was both male and royal. In our African contexts though, if there are any adherents to Christianity and its sacred texts, irrespective of the gender of the author(s) of the texts, these would be African women. As an HIV and AIDS sufferer appropriates the language of honesty displayed by the psalmist, as she cries out her frustrations, pain and restlessness to the God in whom she trusts, the fact that the psalm could have been originally prayed by David, the man and David, the king, would not matter to her.

Thus, on account of the psalms' timeless and open-ended nature, Psalm 6 can also be appropriated by present day AIDS sufferers.

In the context of HIV and AIDS, the pray-er or sufferer or lamenter is first and foremost a believer, a Christian woman who may not necessarily have the medical resources to take care of her severe sickness (read: opportunistic diseases caused by AIDS). The lamenter would most probably be women whose cd count had gone so low that their bodies would be deteriorating day in and day out (Ps 6:2). Although their physical bodies are failing them, their spirits are still alive and their faith in God still intact (Ps 6). Unlike many fellow believers including both clergy and laity, who had told them that they contracted the virus because of their sins, these women, like the lamenter in Psalm 6, are not persuaded that they are sick because they had sinned, hence no confession of sin as the lament of Psalm 6 opens. ${ }^{5}$ However, on account of the African causative worldview, and the pressure from the many believers who accuse them of having sinned, these women, like the psalmist could attribute their illness to God's punishment. McCann (1996) reasons that Psalm 6 may be testifying that in each experience of life, God is present (McCann 1996:704). The psalm may point to the ancient belief that sin caused disease, however seeing that it does not contain any specific confession of sin, it might be pointing to the reality of God in each situation (McCann 1996:703).

On account of the severity of the psalmist's condition ${ }^{6}$, we can rightly speculate that the condition of the female sufferer had shifted from an HIV positive status to that of the opportunistic diseases caused by AIDS. As a committed believer who is convinced that her life both in sickness and in health should glorify God and thus reveal her close relationship with God, the AIDS sufferer is lamenting her way through to God for God's sake. Her enemies, whether systemic or human, will come to acknowledge through her deliverance from sickness that God is on her side and that God delights in providing blessings (read: physical health) to those who approach Yahweh with a stubborn faith and a determination to hope against hope.

In our view, unlike the lamenter in Psalm6 who did not believe that God could still be praised by believers after death (read: in Sheol $^{7}$ ), the lament by the AIDS sufferer would be persuaded by her Christian belief that God takes sides with those who are in bondage (cf. Ex 3:7-8). She will also be persuaded by her belief in the Redeemer who came that his sheep might have life and life in abundance (Jn 10:10). As the psalmist, we live daily with the stark realities of terror, disease, weariness, grief, and the awareness that we are mortal beings. These according to the psalmist though are not powerful enough to separate us from the love of God '... without minimizing the difficulties of life, Psalm 6 offers a resounding "yes to life," grounded not in self-confidence but in the steadfast love of God(v.4)' (McCan1996:706).

5.We therefore beg to differ with Habtu when he argues that "His(the Psalmist experience shows that suffering can indeed be God's discipline ...' (Habtu 2006:613).

6.Like Psalms 38, 41, 88 and 102, Psalm 6 is the prayer of a very sick person (Habtu 2006:613; cf. also. Rakes 2002:292).

7.In Hebrew thought, Sheol is the grave, a place of murky silence. It is a place of no return with little or no contact with Yahweh (Ps 94:17; Ps 143:3; Job 7:9), and thus no possibility for praising God there. The concern for healing and deliverance by the no possibility for praising God there. The concern for healing and deliverance by the postexilic age was the notion of God's presence with the dead in Sheol accepted postexilic age was the notion of God's presence with the dead in Sheol accepted
(Ps 139:8). Belief in life after death is found earlier on within popular religious beliefs (1 Sm 28:8-25; 2 Ki 2:11; Stuhlmueller 1988:433-494). 
As already noted with Miller above, any condition of (severe) sickness has the capacity to lead the victim to a state of helplessness and even hopelessness. What exacerbates the situation of HIV and AIDS sufferers, particularly in our African Christian contexts are the following factors among others: the association of the pandemic with sex and sexuality. The engagement with the preceding themes is a taboo within various African contexts (cf. Kathide 2003:1-9). What complicates the situation for African AIDS sufferers is the stigma connected with illicit sex and thus the belief that the sufferers are incurring God's punishment (Madipoane Masenya [ngwan'a Mphahlele] 2005c). It makes sense that in the preceding contexts, the sufferer may not only feel helpless, but also isolated. Indeed, in some cases, the sufferers are isolated even by their families until death! The deep sighing, the constant tears, the groaning and moaning, all directed to God, make perfect sense within such contexts. Many AIDS sufferers, thus, find themselves dangling between death and hope; some like the psalmist end up with deliverance, while many others, in line with the fear of the psalmist, end up in death.

Within the context of the crisis brought by HIV and AIDS, the following prayer items would in our view form the gist of the individual lament. To use the language of the psalmist, such items among others may be viewed as some of the enemies she has to grapple with: (1) the stigma around HIV and AIDS, one which keeps the infected isolated even by members of their faith communities. We are here reminded of the words of Beverly Haddad (2003) about the deafening silence of the church on the pandemic of HIV and AIDS. (2) The entrenched inequities between women and men, in which male headship and female subordination are sanctioned as God-ordained. Such inequities usually make it almost impossible for women to negotiate safe sex. (3) Dangerous notions of masculinities through which gender-based violence is perpetuated. (4) Greedy and corrupt rulers who have no capacity to deal with poverty head on. (5) Ruthless empires.

In a moment of crisis, a poor African woman does not have the capacity to spend money on a well-balanced diet and medicine among others. As she dangles between death and hope, she is sustained by her faith in the God who hears and answers prayer. Indeed the lament psalms display faith under the most contrary circumstances (cf. Broyles 2008:396). Her ability to see beyond her poverty and her worn-out body enables her to dare to dream even in her moment of crisis. As has been argued by Graic Broyles: 'Assumed here is that God can be moved not only emotionally, as expressed in the laments, but also by reason and by argument' (Broyles 2008:396). In Psalm 6, for example, the appeal is threefold. Firstly, it pits Yahweh's 'loyalty' (hesed) against his wrath. Secondly, it seeks to move him to pity and healing by focusing on the intensity (e.g. 'my bones shake in horror') and duration (how long?) of the distress. Thirdly, 'it seeks rescue from death so that God's worshiper and God's praise may continue' (Broyles 2008:396). A lament psalm can thus not invest interest in philosophical abstractions. Its theological vision is firmly rooted in the themes of suffering and justice that constitute the thematic heart of lament psalms. The relationship between suffering, God and justice is more or less explicit throughout each lament psalm (Mandolfo 2014:125). In the following lines, we offer a translation of Psalm 6 from the New Revised Standard Version followed in brackets, by a possible re-reading of the psalm by the AIDS sufferer.

\section{Lamenting her way between death and hope: The cry by the AIDS sufferer}

1. O Lord, do not rebuke me in your anger, or discipline me in your wrath. (Oh Lord, spare me from your heated wrath, your anger overwhelms me)

2. Be gracious to me, $\mathrm{O}$ LORD, for I am languishing; $\mathrm{O}$ LORD, heal me, for my bones are shaking with terror. (Carrying an AIDS-ravaged body, I feel exhausted, hasn't hunger also taken its toll on me? Have mercy...)

3. My soul also is struck with terror, while you, O LORD how long? (For how Long, will I have to suffer, my soul deeply unsettled, why should the innocent righteous suffer?)

4. Turn, O LORD, save my life; deliver me for the sake of your steadfast love. (Remember my poverty, my plight, in your loving kindness redeem me from this body of death)

5. For in death there is no remembrance of you; in Sheol who can give you praise? (Does Sheol know any remembrance of you, No it doesn't! So, save me...)

6. I am weary with my moaning; every night I flood my bed with tears; I drench my couch with my weeping. (My tears are my food, exhaustion my lot, My God, ill- health is wearing me off)

7. My eyes waste away because of grief; they grow weak because of all my foes. (My enemies, stigma, poverty, patriarchy, Empire, detached political and religious leaders, overwhelm my body with grief)

8. Depart from me, all you workers of evil, for the LORD has heard the sound of my weeping. (In your loving kindness oh Lord, you have heard my prayer, you evil systems, you violators of female bodies, you, even you can never have a hold over me! Go away!)

9. The LORD has heard my supplication; the LORD accepts my prayer. (Amidst death, I have hope, the Lord has heard my prayer, I am thus alive!)

10. All my enemies shall be ashamed and struck with terror; they shall turn back, and in a moment be put to shame. (To my enemies, shame on you!)

In the preceding text, Psalm 6 in the New Revised Standard Version is presented, followed by our re-reading form. The reconstruction of the biblical text using the language and concepts which are relevant to a particular context, is not a new phenomenon in African Biblical hermeneutics. In his proposal of the creation of religious texts, Snyman (2003:116123) suggests that a modern reader of the Hebrew Bible may reconstruct a biblical text in such a way that it unlocks the reality of his or her audience (cf. Masenya [ngwan'a Mphahlele] 2005a:186). Drawing on Snyman's idea of the 
reconstruction of religious texts, we have attempted a rereading of Psalm 6 from a gender-sensitive HIV and AIDS perspective.

As already noted, the sufferer in our re-reading of Psalm 6 is not only sick, he is very sick, thus nearing death. What would be fascinating to present day African readers of this lament is that the man who was crying out the lament did not shy away from crying out to God. In the midst of any crisis, what counts the most is not that a particular gender is the one to blame and thus to suffer, what is more urgent is that human life, whether male or female, rich or poor, black or white among others, is at stake. Human life is threatened. One is injured. So all are and should be equally injured. Walking in the shadow of the valley of death on account of his physical, emotional and psychological health among others, did not deter the psalmist from holding on to a stubborn hope. Amidst death-dealing situations such as the one in which we all have been thrown into by the pandemic of HIV and AIDS, as well as hopelessness, a lament can serve as a vehicle for the down-trodden, the sufferers, the justice-seekers to remain sustained, to dare to dream because, argues Katongole (2012):

... a biblically inspired social engagement in the era of HIV/ AIDS, rather than being grounded in an activist paradigm, needs to grow out of, and be deeply connected to, a biblically inspired discipline of lament. The reason for this has to do not only with the fact that the stubbornness to dream of God's new creation in the wake of AIDS involves the discipline of sustained memory, but also with the realization that dreaming is deeply engaged commitment that requires community. (p. 41)

\section{Conclusion}

Tau tša hloka seboka, di šiwa ke nare e hlotša [lions that are divided are outran by a limping buffalo]. Indeed, an injury to one is an injury to all. Within the exilic and post-exilic contexts, contexts in which the Jews had to ensure that they knew who they were and clung to their identity, settings in which they had to continue to exist and flourish in the midst of hostilities, it is possible that individual psalms of lament such as Psalm 6 above might have assumed a communal meaning. Indeed, moments of crises have their way of persuading even the most divisive among us, to cling together against the one enemy. HIV and AIDS have come to wreak havoc on the globe, particularly within the povertystricken parts of the globe. All of humanity is either infected or affected. All of us therefore have to engage in an active act of lamentation. Our justice-seeking struggle must remain fierce as we continue to dangle between faith and doubt, courage and despair, death and hope also stubbornly holding onto the faith that the God of life has the power to right the wrong.

\section{Acknowledgements Competing interests}

The authors declare that they have no financial or personal relationships which may have inappropriately influenced them in writing this article.

\section{Authors' contributions}

M.M. and V.N.N.M. of the University of South Africa were project leaders and as such, they were responsible for the conceptual contributions.

\section{References}

Amoah, E., 2009, "Poverty is madness": Some insights from traditional African spirituality and mental health', in D.N. Hopkins \& M. Lewis (eds.), Another world is possible: Spiritualties and religions of global darker peoples, pp. 207-218, Equinox, London.

Amoah, E. \& Oduyoye, M.A., 1989, 'The Christ for African women', in V. Fabella \& M.A. Oduyoye (eds.), With passion and compassion: Third World Women doing theology, pp. 35-46, Orbis, Maryknoll.

Ayanga, H., 2008, 'Religio-cultural challenges in Women's fight against HIV/AIDS in Africa', in T. Hinga (ed.), Women, Religion and HIV/AIDS in Africa: Responding tgo ethical and theological challenges, pp. 34-48, Cluster, Pietermaritzburg.

Bowser, B.P., 1994, 'Black men and AIDS: Prevention and sexuality', in R.G. Majors \& J.U. Gordon (eds.), The American black male: His present status and his future, pp. 115-126, Nelson-Hall, Chicago, IL.

Broyles, C.C., "'Lament of," in T. Longman, \& P. Enns (eds.), Dictionary of the Old Testament wisdom, poetry and writings, pp. 384-399, InterVarsity Press Academic, Downers Grove, II.

Chauke, E., 2003, 'Theological challenges and ecclesiological responses to women experiencing HIV/AIDS: A South Eastern Zimbabwe context', in I.A. Phiri, experiencing HIV/AIDS: A South Eastern Zimbabwe context', in I.A. Phiri, B. Haddad \& M. Masenya (ngwan'a Mphahlele) (eds.), African
and faith communities, pp. 128-138, Cluster, Pietermaritzburg.

Chitando, E. \& Chirongoma, S., 2008, “Challenging masculinities: Religious Studies, men and HIV in Africa." Journal of Constructive Theology (14)1, 55-69.

Cole, J.B. \& Guy-Sheftall, B., 2004, 'Gender talk: The struggle for women's equality in African American communities, Ballantine Books, New York.

Declaissé-Walford, N.L., 2012, 'Psalms', in C.A. Newsom, S.H. Ringe \& J.E. Lapsley (eds.), Women's Bible commentary, 20th edition, pp. 221-231, Westminster John Knox, Louisville, KY.

Dube, M.W., 2000, Postcolonial feminist interpretation of the Bible, Chalice, St. Louis, MO.

Dube, M.W., 2009, 'HIV and AIDS research and writing in the circle of African women theologians 2002-2006', in E. Chitando \& N. Hadebe (eds.), Compassionate circles: African women theologians facing HIV, pp. 173-196, World Council of Churches Publications, Geneva.

Dube, M.W., 2012, 'Go Tla Siama, O Tla Fola': Doing Biblical studies in an HIV and AIDS Context', in M.W. Dube, A.M. Mbuvi \& D.R. Mbuwayesango (eds.), Postcolonia perspectives in African Biblical Interpretations, pp. 483-508, SBL, Atlanta, GA.

Fontaine, C.R., 1992, 'Proverbs', in C.A. Newsom \& S.H. Ringe (eds.), The Women's Bible commentary, pp. 145-152, Westminster/John Knox Press, Louisville, KY.

Dube, M.W. \& Kanyoro, M. (eds), 2004, Grant Me Justice! HIV/AIDS \& Gender Readings of the Bible, Cluster Publications, Pietermaritzburg; Orbis Books, Maryknoll.

Goldingay, J., 2006, Psalms, volume 1: Psalms 1-41, Baker Academic, Grand Rapids, MI.

Habtu, T., 2006, 'Psalms', in T. Adeyemo (ed.), Africa Bible commentary, pp. 605-746, WorldAlive Publishers, Nairobi

Haddad, B., 2003, 'Choosing to remain silent: Links between gender violence, HIV/ AIDS and the South African Church', in I.A. Phiri, B. Haddad \& M. Masenya (ngwan'a Mphahlele) (eds.), African women, HIV/AIDS and faith communities, pp. 149-167, Cluster, Pietermaritzburg.

Hinga, T.M., 1992, 'Jesus Christ and the liberation of women in Africa', in M.A. Oduyoye \& M.R.A. Kanyoro (eds.), The will to arise: Women, tradition, and the church in Africa, pp. 183-194, Orbis, Maryknoll.

Hinga, T.M., Kubai, A.N., Mwaura, P. \& Ayanga, H. (eds.), 2008, Women, religion and HIV/AIDS in Africa: Responding to ethical and theological challenges, Cluster Publications, Pietermaritzburg.

Hirschowitz, R., Worku, S. \& Orkin, M., 2000, Quantitative research findings on rape in South Africa, Statistics South Africa, Pretoria.

Kathide, A.G., 2003, 'Teaching and talking about our sexuality: A means of combating HIV/AIDS', in M.W. Dube (ed.), HIV/AIDS and the curriculum: Methods of integrating HIV/AIDS in theological programmes, pp. 1-9, WCC Publications, Geneva.

Katongole, E., 2012, 'Embodied and embodying hermeneutics of Life in the academy: Musa W. Dube's HIV/AIDS work in postcolonial perspectives in African biblical Musa W. Dube's HIV/AIDS work in postcolonial perspectives in African biblical
interpretations', in M.W. Dube, A.M. Mbuvi \& D.R. Mbuwayesango (eds.), Postcolonial perspectives in African biblical interpretations, pp. 407-415, Society Postcolonial perspectives in African
of biblical Literature, Atlanta, GA.

Kretzschmar, L., 1992, 'The relevance of feminist theology within the South African context', in D. Ackermann, J.A. Draper \& E. Mashinini (eds.), Women hold up half the sky: Women in the church in South Africa, pp. 106-121, Cluster, Pietermaritzburg.

Mandolfo, C., 2014, 'Language of lament in the psalms', in W.L. Brown (ed.), The Oxford handbook of the psalms, pp. 114-130, Oxford University Press, Oxford.

Masenya (ngwan'a Mphahlele), M., 2001, 'Between unjust suffering and the "silent" God: Job and HIV/AIDS sufferers in South Africa', Missionalia 29(2), 186-199.

Masenya (ngwan'a Mphahlele), M., 2002, “....but you shall let every girl live”: Reading Exodus 1:1-2:10 the bosadi (womanhood) way', Old Testament Essays 15(1), 99-112. 
Masenya (ngwan'a Mphahlele), M., 2003a, 'Trapped between two "canons": AfricanSouth African Christian women in the HIV/AIDS era', in I.A. Phiri, B. Haddad \& M. Masenya (ngwan'a Mphahlele), African women, HIV/AIDS and faith communities,

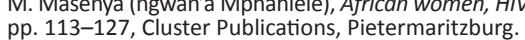

Masenya (ngwan'a Mphahlele), M., 2003b, 'Sacrificing female bodies at the altar of male privilege: A bosadi reading of Judges 19', Theologia Viatorium 27(1), 98-122.

Masenya (ngwan'a Mphahlele), M., 2004, How worth is the woman of worth? Rereading Proverbs 31:10-31 in African-South Africa, Peter Lang, New York.

Masenya (ngwan'a Mphahlele), M., 2005a, 'HIV/AIDS and African Biblical Hermeneutics: Focus on Southern African Women', Chakana 3, 21-35.

Masenya (ngwan'a Mphahlele), M., 2005b, 'Their hermeneutics was strange! Ours is a necessity! Rereading Vashti as African-South African women', in C. Vande Stichele \& T. Penner (eds.), in Her master's tools? Feminist and postcolonia engagements of historical-critical discourse, pp. 179-194, Society of Biblical Literature, Atlanta, GA.

Masenya (ngwan'a Mphahlele), M., 2005c, 'The optimism of the wise in Africa and in Israel: How helpful in the time of HIV/AIDS?', Old Testament Essays 18(2), 296-308.

Masenya (ngwan'a Mphahlele), M., 2005d, 'An African methodology for South African biblical sciences: Revisiting the bosadi (womanhood) approach', Old Testament bssays 18(3), 741-751.

Masenya (ngwan'a Mphahlele), M., 2005e, 'The Bible, HIV/AIDS and African/South African women: A bosadi approach', Studia Historiae Ecclesiaticae XXXI (1), 187-201.

Masenya (ngwan'a Mphahlele), M., 2006a, 'Killed by Aids and buried by religion: African female bodies in crisis', Old Testament Essays 19(2), 486-499.

Masenya (ngwan'a Mphahlele), M., 2006b, 'Challenging poverty through Proverbs: An African transformational hermeneutic', Old Testament Essays 19(2), 393-404.

Masenya (ngwan'a Mphahlele), M., 2007, 'Seeking security through marriage: Ruth 1:6-18 Placed under an African woman's HIV and AIDS lens', Journal of Constructive Theology 13(2), 43-56.

Masenya (ngwan'a Mphahlele), M., 2008, 'An African-conscious female's reading of Steve Biko', in C.W. du Toit (ed.), The legacy of Steve Biko: Theological challenges, pp. 141-155, Institution for Religion and Theology, Unisa.

Masenya (ngwan'a Mphahlele), M., 2013, 'Engaging with the Book of Ruth as single African Christian Women: One African Christian Woman's Reflection', Verbum et Ecclesia 34(1), 9 pages, http://dx.doi.org/10.4102/ve.v34:1.771

Masenya (ngwan'a Mphahlele), M., 2012, 'Without a voice, with a violated body: Re-reading Judges 19 to challenge gender violence in sacred texts', Missionalia 40(3), 205-216.

Masenya (ngwan'a Mphahlele), Madipoane and Bookholane, Lehlogonolo, 2011 'Towards an ethical reading of the Hebrew Bible in the fight against HIV and AIDS', Old Testament Essays 24(1), 94-117.

Mashau, T.D., 2003, 'Africanisation of Christianity and theology: A reformational perspective', Theologia Viatorium 27(1), 123-143.
Mbuwayesango, D.R., 2007, 'Levirate marriage and HIV and AIDS in Zimbabwe: The story of Judah and Tamar (Genesis38)', Journal of Constructive Theology 13(2), 5-15.

McCann, J.C. (Jr), 1996, 'Psalms', in L.E. Keck (ed.), The Interpreter's bible in Twelve volumes, Volume IV, pp. 641-1280, Nashville, Abingdon.

Miller, P.D., 1986, Interpreting the psalms, Fortress, Philadelphia, PA.

Mofokeng, T., 1986, 'The evaluation of the Black struggle and the role of Black Theology', in I.J. Mosala \& B. Tlhagale (eds.), The Unquestionable Right to Be Free: Black Theology from South Africa, pp. 113-128, Skotaville, Braamfontein.

Mwaura, P.N., 2008, 'Stigmatization and discrimination of HIV/AIDS women in Kenya: A violation of human rights and its theological implications', Exchange 37, 35-51. http://dx.doi.org/10.1163/157254308X251322

Nadar, S., 2004, "Barak God and die!" Women, HIV and a theology of suffering', in M.W. Dube \& M. Kanyoro (eds.), Grant me justice: HIV/AIDS \& gender readings of the Bible, pp. 60-79, Cluster, Pietermaritzburg.

Oduyoye, M.A., 1994, 'Feminist theology in African perspective', in R. Gibellini (ed.), Paths in African theology, pp. 166-181, Maryknoll, Orbis.

Okure, T., 2003, 'Invitation to African women's hermeneutical concerns', African Journal of Biblical Studies (XIX) 2, 71-95.

Olojede, F., 2015, 'Absence of wife battering in Old Testament narratives: A literary omission or a cultural aberration?', in I. Fischer (ed.), Gender agenda matters: Papers of the 'feminist section' of the International Meetings of the Society of Biblical Literature, pp. 87-98, Cambridge Scholars Publishing, Newcastle upon Tyne.

Phiri, I.A., 2003, 'African women of faith speak out in an HIV/AIS era', in I.A. Phiri, B. Haddad \& M. Masenya (ngwan'a Mphahlele) (eds.), African women, HIV/AIDS and faith communities, pp. 3-20, Cluster, Pietermaritzburg.

Phiri, I.A. \& Nadar, S., (eds.), 2006, African women, religion and health: Essays in honor of Mercy Amba Ewudziwa Oduyoye, Orbis Books, Maryknoll.

Rakes, G.M.N., 2002, 'Psalms', in C.C. Kroeger \& M.J. Evans (eds.), The IVP Women's Bible commentary, n.p., InterVarsity Press, Downers Grove, IL.

Rivkin, E.T., 1994, 'The Black Woman in South Africa', in C.F. Steady (ed.), The black woman cross-culturally, pp. 215-229, Schenkman Books, Rochester.

Rodney, H., 1982, How Europe Underdeveloped Africa, Howard University Washington.

Snyman, G.F., 2003, From text to sermon: Reading and creating religious texts: Only guide for CGM303-U, University of South Africa Press, Pretoria.

Staples, R., 1978, 'Masculinity and race: The dual dilemma of black men', Journal of Social Issues 34, 169-183. http://dx.doi.org/10.1111/j.1540-4560.1978.tb02547.x Steady, F.C., 1994, The black woman cross-culturally, Schenkman books, Vermont.

Stuhlmueller, C., 1988, 'Psalms', J.L. Mays (eds.), Harper's Bible commentary, pp. 433-494, Harper and Row Publishers, San Francisco, CA.

Teffo, L.J., 2003, 'Healing: An Enduring Feature of African Religions', Theologia Viatorium 27(1), 165-182. 